\title{
Aquatic macrophytes and trophic interactions: a scientometric analyses and research perspectives
}

\author{
C. M. C. Rocha a, D. Lima ${ }^{b}$, M. C. C. Cunha ${ }^{c}$ and J. S. Almeida ${ }^{a *}$ \\ áLaboratório de Interações Multitróficas - LIM, Programa de Pós-graduação em Biologia Vegetal, Departamento \\ de Biociências, Universidade Federal de Pernambuco - UFPE, Av. Prof ${ }^{\mathrm{o}}$ Moraes Rêgo, s/n, Cidade Universitária, \\ CEP 50670-90, Recife, PE, Brasil \\ bDepartment of Water Quality Control, Berlin Institute of Technology - TU Berlin, Straße des 17. Juni, 135, KF4, 10623, \\ Berlin, Germany \\ c Núcleo de Pesquisas em Ecossistemas Aquáticos - NUPEA, Departamento de Educação, Universidade do Estado da \\ Bahia - UNEB, Rua da Gangorra, 503, Gal. Dutra, Campus VIII, CEP 48608-240, Paulo Afonso, BA, Brasil \\ *e-mail: jacortez@ufpe.br
}

Received: September 19, 2017 - Accepted: March 6, 2018 - Distributed: November 30, 2019

(With 8 figures)

\begin{abstract}
Aquatic macrophytes have a recognized role in ecosystem structuring and an important position in trophic cascades interactions, whose understanding is to improve water quality. In recent years, the number of studies on the role of aquatic macrophytes in trophic webs and interactions has increased, but South America has made little progress in research in the area. In this study, we investigated the main gaps and perspectives for future studies on macrophytes and trophic interactions, analyzing global publications, especially those conducted by South American researchers. We accessed publications using an international database (Thomson Reuters ISI-Web of Knowledge-(formerly Institute for Scientific Information)) from 1980 to 2015 . We ranked each article by ecosystem and study approach, biological organization and interacting taxonomic groups (phytoplankton, periphyton, zooplankton, aquatic invertebrates, fish and birds), countries publishing in cooperation and affiliations. The results showed that published studies $(\mathrm{n}=242)$ emphasizing aquatic plants in trophic interactions increased in 35 years. Comparing the contributions of the 32 countries investigated, those from South America as first affiliation, had few publications $(\mathrm{n}=26)$ and in cooperation $(\mathrm{n}=7)$. The largest volume of articles indexed by the researchers dealt with the dynamics and structure of aquatic assemblages, webs and trophic interactions. Ecosystems such reservoirs and wetlands have received little attention. Large numbers of studies have encompassed community-wide aquatic approaches, including in South American studies, the interactions between macrophytes, zooplankton and phytoplankton were the second most studied interactions of all indexed articles. Knowledge about trophic cascade and interactions has been successfully enhanced in several countries with the purpose of restructuring communities and restore water quality of many ecosystems. In summary, we conclude that studies in the area of trophic interactions mediated by macrophytes may be directed in a way to attenuate international asymmetries, encouraging the increase of scientific productivity in South America.
\end{abstract}

Keywords: aquatic macrophytes, scientometric analyses, South America, trophic interactions, tropical reservoir.

\section{Macrofitas aquáticas e interações tróficas: análise cienciométrica e perspectivas nas pesquisas}

\section{Resumo}

Macrófitas aquáticas tem reconhecida função na estruturação de ecossistemas e importante papel nas interações tróficas em cascata, cujo entendimento é chave para melhorar a qualidade da água. Nos últimos anos, o número de estudos sobre o papel das macrófitas aquáticas nas interações e teia trófica aumentaram mas, a América do Sul progrediu pouco em pesquisas na área. Nesse estudo investigamos as principais lacunas e perspectivas para estudos futuros sobre macrófitas e interações tróficas analisando publicações mundiais, especialmente aquelas conduzidas por pesquisadores sul-americanos. Acessamos publicações usando base de dados internacional (Thomson Reuters ISI Web of Knowledge) entre 1980 a 2015. Computamos para cada artigo a organização biológica e grupos taxonômicos em interação (fitoplâncton, perifíton, zooplâncton, invertebrados aquáticos, peixes e aves), ecossistema estudado e abordagem de pesquisa, a cooperação entre países da América do Sul e demais, além das filiações. Os resultados mostraram que estudos publicados $(n=242)$ enfatizando plantas aquáticas em interações tróficas cresceram em 35 anos. Comparando as contribuições dos 32 países investigados, aqueles da América do Sul apresentaram baixo número de indexações 
$(n=26)$, poucos em cooperação $(n=7)$. O maior volume de publicações indexadas pelos pesquisadores trataram sobre a dinâmica e estrutura das assembléias aquáticas, teias e interações tróficas. Reservatórios e áreas alagadas têm recebido pouca atenção. Grande número de estudos compreeenderam abordagems de toda comunidade aquática e interações entre macrófitas, fitoplâncton, zooplâncton e peixes. Em síntese, concluimos que estudos enfatizando as interações tróficas mediadas pelas macrófitas poderão ser direcionados de maneira a atenuar assimetrias internacionais, encorajando o aumento da produtividade científica na América do Sul. O conhecimento sobre as interações tróficas em cascata tem sido desenvolvido com sucesso em diversos países cujas finalidades tem sido reestruturar comunidades e restaurar a qualidade da água de muitos ecossistemas.

Palavras-chave: macróftas aquáticas, análise cienciométrica, América do Sul, interações tróficas, reservatórios tropicais.

\section{Introduction}

Aquatic macrophytes play fundamental roles in the structure and function of ecosystems (Thomaz and Cunha, 2010). They are one of the major components of freshwater environments, increasing the biodiversity patterns, especially species richness and communities composition (Thomaz et al., 2009; Kovalenko et al., 2011). Several factors contribute to the impact of macrophytes in trophic cascades (Jeppesen et al., 2005), which affect greatly aquatic food webs through physical, chemical and biological mechanisms (Canfield et al., 1984; Carpenter and Lodge, 1986; Dent et al., 2002). The effect of the physical architecture of macrophytes determine habitat complexity to a wide range of planktonic and benthic animals (Thomaz et al., 2008). Submerged forms in particular promote trophic interactions that benefit the entire ecosystem (Scheffer et al., 1993). Their extensive coverage enhance the transparency of water by favouring the reduction of the resuspension of bottom material (Carpenter and Lodge, 1986; Scheffer, 1999). In addition, the excretion of allelopathic sustances of submerged plants are responsible for algal growth impairment (van Donk and van de Bund, 2002). Under these cirscunstances, aquatic plants promote top-down effects by reduction of the grazing of fish on zooplankton, and bottom-up effects by reducing nutrients availability in the water column and consequently controling phytoplankton growth (Dent et al., 2002).

In temperate countries, the interest in aquatic interactions and cascading effects has emerged as one of the central issues to reduce the formation of phytoplankton biomass (Carpenter et al., 1985) since the first successful studies carried out by Shapiro et al. (1975). Interpreting food web and the trophic cascades consisted in understanding the role of aquatic vegetation in the processes that mediate interactions, especially in the tropics where few studies has been developed (Jeppesen et al., 2012). Studies on aquatic trophic webs are not abundant in South America. Such research is important for the advancement of theoretic and applied aquatic ecology and an essential step to the management, planning and restoration environments (Tao et al., 2015).

A wide range of indicators for measuring and mapping results of scientific and technological activities has developed in recent years. Following this progress, scientometric research has become a critical tool, identifying gaps and perspectives for science to develop (Verbeek et al., 2002).
As a quantitative research tool, it aims at improving the interface of pertinent issues to the society, to which more attention should be expended (Van Raan, 1997).

There are still many unanswered questions regarding the effects of macrophytes mediating trophic interactions in tropical environments. In this sense, we focus on finding the main perspectives and gaps for future research addressing these subjects. This study aims at assessing how much the global scientific production has advanced from the scientometric point of view, emphasizing the contributions of South American research. We addressed questions to quantify how much scientific production on macrophytes and trophic interactions increased over time and the main countries involved; of the total amount of publications, how much South America research contributed, the level of international cooperation, which journals published the most volume of studies, what are the research approaches and at last, what are the main researched trends. Our hypothesis is that the number of articles in the field shows a growing tendency over the years, for which the countries of South America have a great contribution in both, the number of publications and international cooperation. We do not intend to be conclusive in this approach, but to highlight some important contributions of the studies that have been developed since then.

\section{Material and Methods}

The online database of Science Citation Index published by the Institute for Scientific Information (ISI, 2015) indexes more than 8,000 scientific journals in 36 languages, representing most significant material in science and engineering at a global level. The ISI was used to collect studies published in leading journals on freshwater ecosystems between 1980 and 2015, with reference to aquatic macrophytes mediating trophic interactions. The survey of articles was assessed by combining keywords in the fields of title, abstract and text body. The following terms were combined: submerged macrophytes or macrophytes or aquatic plants and phytoplankton or plankton or planktonic community or phytoplankton and zooplankton and trophic levels or throfic interactions or throphic web. All articles were ranked according to the first author affiliation. Subsequently, the documents were selected by the information on the country, authorship affiliation, area of study, international cooperation and journal. Additionally, we groupped the informations to identify trends and gaps: i) approach of 
research: experimental, data collection (survey), revision or modelling; ii) studied ecosystem: river/stream, experiments in laboratories, wetlands (flooded areas, estuaries and marshes), reservoirs and reviews; iii) main researched areas investigated: Community dynamics; trophic interactions; trophic webs; biomanipulation; lake ecology; dynamics of populations; community ecology; nutrient cycling; ecotoxicology; restoration; primary productivity; modelling; iv) level of organization: entire community, ecosystem ecology; trophic interactions; dynamics of populations; trophic web; v) component of aquatic ecosystems: aquatic community (entire aquatic community); macrophytes; phytoplankton; zooplankton; invertebrates; vertebrates; interactions between macrophytes and other components such as phytoplankton, periphyton and fish.

We conducted the analysis using Microsoft Excel ${ }^{\circledR}$ and graphs were edited in the RStudio environment version 0.99.903 (R DEVELOPMENT CORE TEAM, 2016).

\section{Results}

The present scientometric analysis comprised scientific papers published in 32 countries over the past thirty-five years. The search engine selected 242 of which were chosen for examination based on the described criteria. The total production of scientific studies on trophic interactions mediated by aquatic macrophytes has increased significantly in thirty-five years $\left(\mathrm{R}^{2}=0.51 ; \mathrm{P}<0.0001\right)$ (see Figure 1). It was observed that in 1990 , the number of published articles was sixteen times higher than the publications number of the 80 s. Similarly happened between the years between 2000 and 2015, whith fifteen times more publications indexed than in the 80 s.

Publications in journals with high impact factor $(>1)$ take place in countries with recognized scientific production. European research encompass $32 \%$ of the global ranking of studies indexed in ISI, headedd by England (7\%), Denmark $(n=6.6 \%)$, Sweden, Netherlands and Belgium with the same percentage (5.8\%), and Germany (5\%) (Figure 2). Research developed in the USA contributed substantially for indexed articles in ISI (18.8\%), in contrast to Canada with only $5.8 \%$ of published paepers. In Asia, China is the most productive country $(5.8 \%)$. On a global scale, international cooperation involved seventeen countries, including South America, and comprised 17\% of all publications $(\mathrm{n}=216)$.

Regarding South American contributions, the scientometrics detected articles published in Argentina,

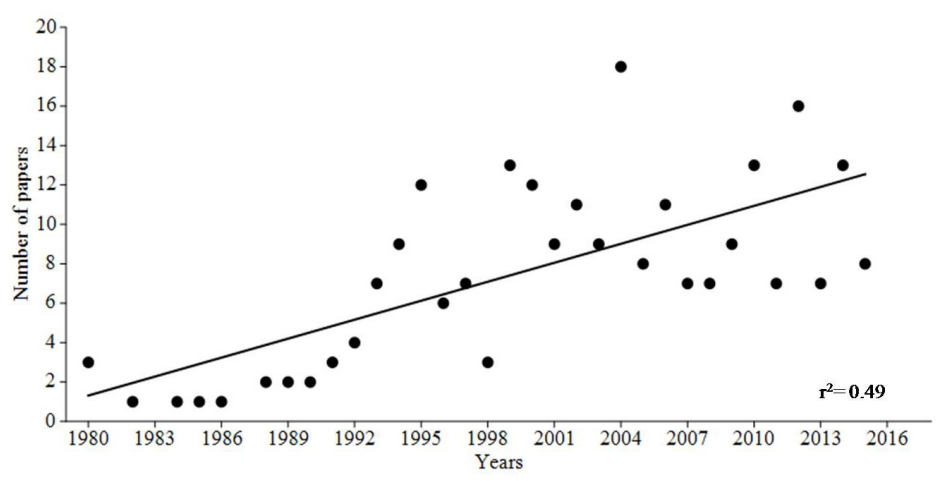

Figure 1. Simple linear regression analysis of the number of papers published worldwide indexed in ISI between 1980 and 2015, on aquatic macrophytes mediated trophic interactions (number of articles $=242$ ).

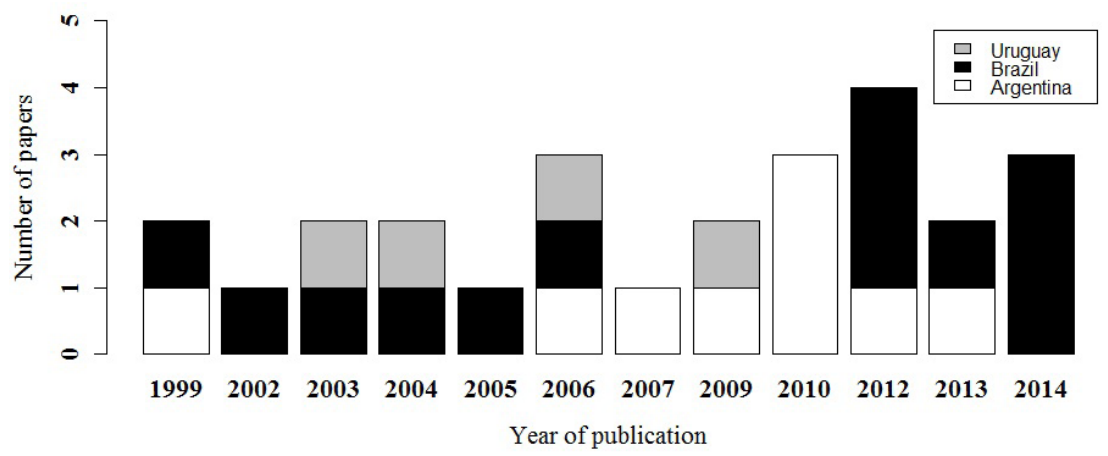

Figure 2. Number of papers published by South American countries indexed in ISI between 1980 and 2015, on aquatic macrophytes mediated trophic interactions $(n=26)$. 
Brazil and Uruguay $(n=26)$ (see Figure 3). Brazilian research $(n=13)$ published more than Argentinian $(n=9)$, and these two countries were the first to publish studies on aquatic weeds mediated trophic interactions in ISI index journals. Uruguay $(n=4)$ has emerged in third place. Together, these three countries gather less than one fourth of the articles published worldwide on the subject. Thirty one percent of papers in South America $(n=8)$ were developed incooperation with Denmark, Senegal, Netherlands and Canada.

There is a large number of journals with scope on aquatic sciences and limnology $(n=89)$. The five journals which published a higher sum of articles wordwide $(n=115)$ in the topic were: Hydrobiologia $(n=58)$, Freshwater Biology ( $\mathrm{n}=32)$, Archives Für Hydrobiology $(\mathrm{n}=11)$, and the journals Ecology and Wetlands $(n=7)$ with the same number of papers. South America published mostly in the two first journals cited above $(n=6 ; 8)$. However, less than $50 \%$ of papers $(n=12)$ has been published in another twelve different journals, including the Brazilian Journal of Biology, an important journal of scientific report in Brazil.

Worlwide research focused mostly in experimental approaches, which encompassed more than $48 \%$ of all publications indexed in ISI $(n=117)$. This data shows the importance of experimentation in studies on aquatic plants and their trophic interactions. In South America the highest number of publications were also made experimentally $(n=13)$ (Figure 4). Surveys methodology still encompass the second most used approach designed to collect data, both globally and in South America ( $\mathrm{n}=99 ; 13$, respectively). However, many other methodologies have been employed around the world but not in South america, such as modelling and revisions, ranked in the thirth position of indexed publications $(\mathrm{n}=13)$.

Lakes and lagoons were the most studied freshwater ecosystems both worldwide and in South America ( $\mathrm{n}=161$; 16 , respectively), followed by rivers ( $n=16 ; 7$, respectively) (see Figure 5). Research developed experimentaly in laboratories and studies conducted in fields contributed worldwide with 15 publications each. Globaly and in South America, reservoirs received little attention $(n=5 ; 3)$, but reviews $(n=3)$ were made just for authors worldwide.

Worldwide, the freshwater research has focused in the understanding of twelve different knowledge areas (see Figure 6). Dynamics of communities are at the top of ranking of investigated fields, worldwide and in South America $(n=48 ; 7)$. Trophic interactions $(n=39 ; 6)$, biomanipulation $(n=39 ; 4)$ and trophic webs $(n=37 ; 7)$ were

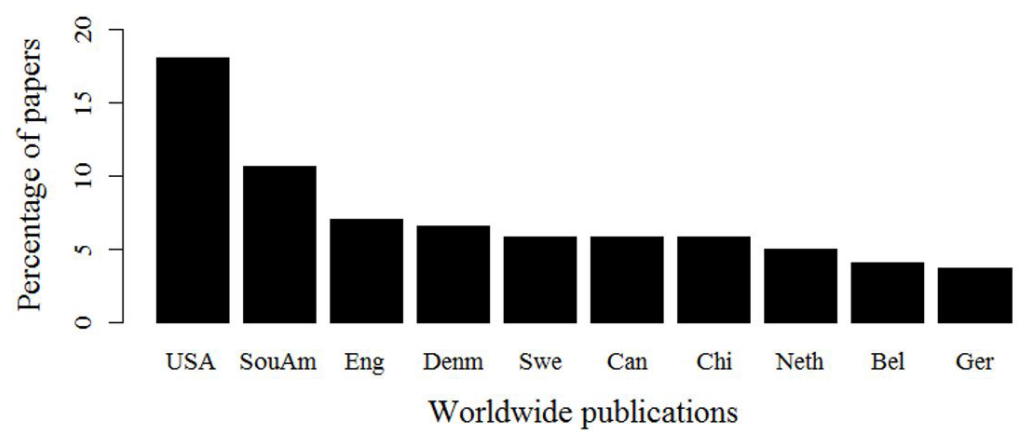

Figure 3. The most productive countries with the highest number of publications (\%) indexed in ISI between 1980 and 2015 on macrophytes mediated trophic interactions $(n=242)$. (Legend: USA = United States of America; SouAm $=$ South America (Argentina, Brazil and Uruguay); Eng = England: Denm = Denmark; Swe = Sweden; Can $=$ Canada; Chi $=$ China; Neth $=$ Netherlands; Bel = Belgium; Ger = Germany)..

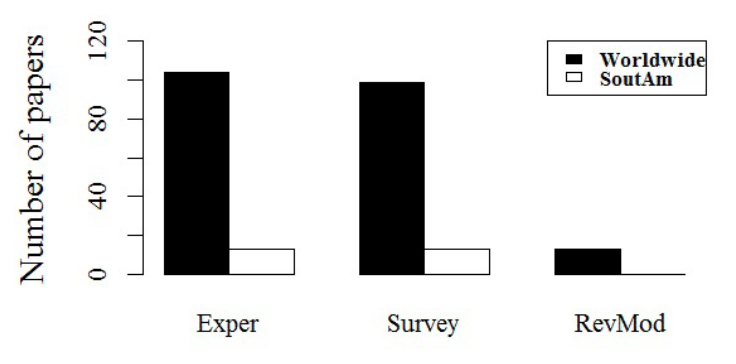

Study approach

Figure 4. Type of approach of researchers developed worldwide and in South America with articles indexed in the ISI between 1980 and 2015 focused studies about macrophyte mediated trophic interactions (number of articles = 242). (Legend: Exper.: experimental, RevMod: revisions and modelling).

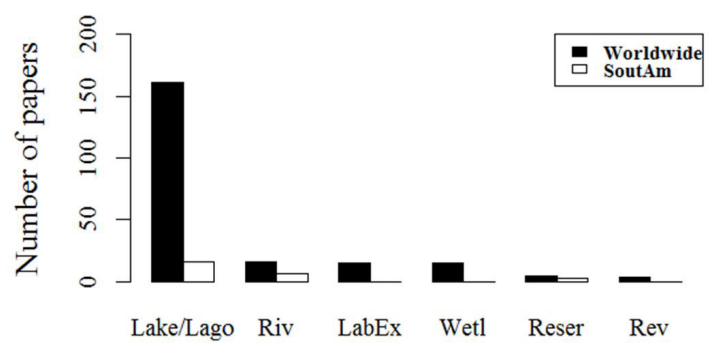

Environment studied

Figure 5. Type of ecosystems studied with publications worldwide and in South America indexed in ISI between 1980 and 2015 on macrophyte mediated trophic interactions (number of articles $=242$ ). (Legend: Riv: river and streams; LabEx: laboratory experiments; Wetl.: wetlands, estuaries and marshes; Reser: reservoirs; Rev: Reviews. 


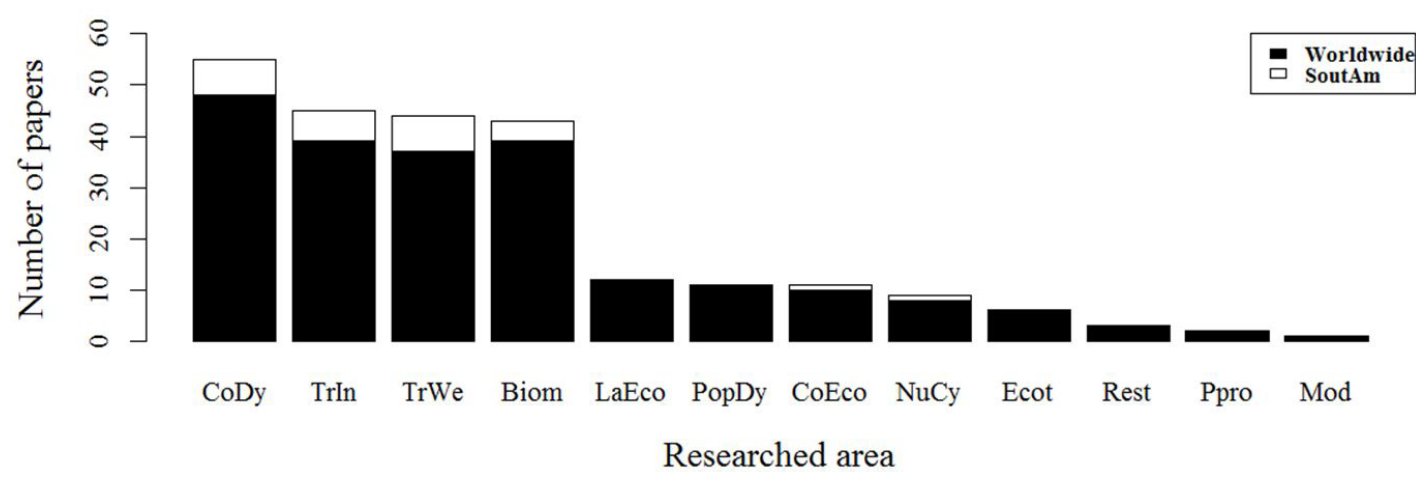

Figure 6. Main researched areas investigated worldwide and in South America (number of papers $=242$ ) with ISI indexed publications between 1980 and 2015 focusing on macrophytes through trophic interactions. Legend: CoDy.: Community dynamics; TrIn.: Trophic interactions; TrWe.: Trophic webs; Biom.: Biomanipulation; LaEco.:Lake ecology; PopDy.: dynamics of populations; CoEco.: Community ecology; NuCy: nutrient cycling; Ecot: Ecotoxicology; Rest.: Restoration; Ppro.: Primary productivity; Mod.: Modelling.

the other areas with higher number of publications indexed in ISI around the word and South America. Ecology of lakes and communities, dynamic of populations, nutrients cycling, ecotoxicology, restoration, primary productivity and modelling congregated $24.5 \%$ of the total amount of papers published worldwide.

Besides the levels of organization and components of aquatic food webs, our data showed that research has mainly focused in understanding the functions and interactions of the aquatic food web as a whole, both worldwide and in South America $(\mathrm{n}=131 ; 18)$ (Figure 7). Trophic interactions and trophic web, and ecology of ecosystems aggregated the second most studied level of organization worldwide $(\mathrm{n}=22 ; 23 ; 12$, respectively), and in countries of South America with only a few number of publications $(\mathrm{n}=2 ; 3)$. Dynamics of populations was the least studied level of organization both worlwide and in South America $(n=9 ; 1)$.

Communities' interactions mediated by macrophytes carried out worldwide and in South America showed that the entire aquatic community $(n=95 ; 12$, respectively) comprised the most number of publications (see Figure 8).

The complexity of research approaches increased along time, and research aimed at understanding the components of the aquatic community. The entire aquatic community appears in the top of those studies around the world and in South America $(\mathrm{n}=95 ; 12)$. In second position, interactions between macrophytes, phytoplankton and zooplankton perform the most studied biological components, both globally and in South America ( $\mathrm{n}=41 ; 8$, respectively). The third ranking of subjects were performed by macrophytes, phytoplankton, zooplankton and fishes with indexed publications only in worlwide research $(n=30 ; 0)$. The interactions between aquatic macrophytes, phytoplankton and zooplankton in association with other components of the food web (fishes, periphyton and invertebrates) contributed significantly for publications worlwide and in South America $(n=20 ; 5)$.

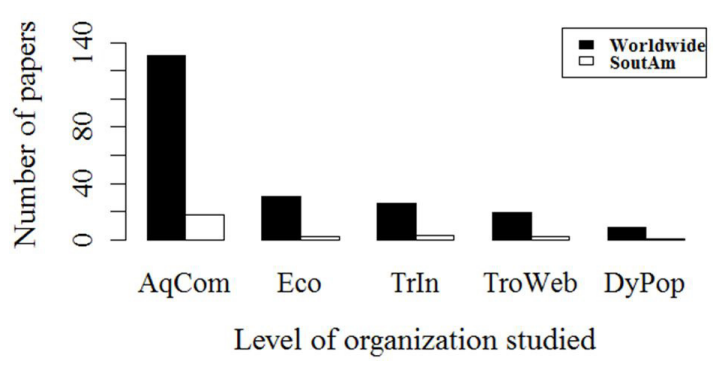

Figure 7. Main trends of level of organization investigated worldwide and in South America (number of papers = 242) with ISI indexed publications between 1980 and 2015 focused studies about macrophytes mediated trophic interactions. Legend: AqCom: entire community; Eco: ecosystem ecology; TrIn.: trophic interactions; Dypop.: dynamics of populations; TroWeb.: trophic web.

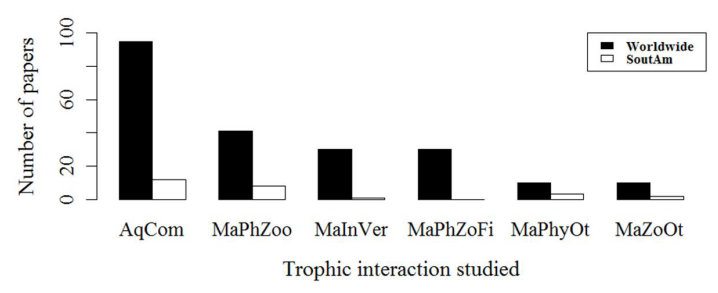

Figure 8. The most investigated trophic interactions worldwide and in South America $(n=242 ; 26)$ focused on macrophytes mediated trophic interactions with publications indexed in the ISI between 1980 and 2015. Legend: AqCom: aquatic community (entire aquatic community); Ma: macrophytes; Ph: phytoplankton; Zoo: Zooplankton; In.: invertebrates; Ver.: vertebrates; Ot: others interactions between macrophytes and other components such as phytoplankton, periphyton and fish. 


\section{Discussion}

Scientometrics is a source of information to map scientific and technological subjects in order to assess meaningful compilation of knowledge on which science heavily relies (Verbeek et al., 2002). The first interesting finding of this study supported our predictions, and showed that the study of aquatic macrophytes mediated trophic interactions has been increasing substantially in the last 35 years. We identified two main phases in which there were a greater contribution of publications worldwide that were in 90s, and between 2000 to 2015. Research in South America needs to develop and expend more efforts in publishing studies on trophic interactions and food webs, especially in environments such as wetlands, reservoirs and rivers. Besides the substantial increase of publications, this investigation showed that over decades, the trends and focus of many studies by limnologists and aquatic ecologists consisted in research with experimental and applied approaches (Padial et al., 2008; Tao et al., 2015). The future step in research consists in identifying problems of endangered ecosystems, find general patterns to conduct successful experimental investigations, and then make interventions for protection of natural areas and conduct restoration of eutrophic freshwater ecosystems. South America has made little progress in this aspect, although the negative anthropogenic impacts on freshwater systems have been increasing pressure on water and land and biodiversity losses (Tundisi et al., 2008; Jeppesen et al., 2012).

Regarding the total volume of articles published in South America, just one third were developed with international cooperation mainly with Denmark and Netherlands. According to this analysis, countries with the highest scientific productivity such as USA and England did not cooperate with Latin countries in studying this topic. Probably, in part because the high investments demand, the geographical distance, bureaucratic and inter-institutional predicaments. In the contrary, USA, United Kingdom and Canada had strong correlation with collaborative studies in network aiming at understanding aquatic ecosystems (Liao and Huang, 2014). USA are in the top of the list with a highest scientific production in several areas of knowledge since years (Cao et al., 2012; Liao and Huang, 2014). Denmark and Canada present the highest number of studies cited globally (Hill, 2004) and the productivity for knowledge of aquatic food webs was high for over 40 years (Tao et al., 2015). But in general, the change and trends of international cooperation among countries and continents understanding food webs were drawn (Tao et al., 2015).

There is a considerable volume of journals devoted to aquatic science studies, which cover a stunning number of topics ranging from molecular studies to literature reviews. In this universe of scientific journals, the Archives Für Hydrobiologie (1906) is one of the first journals in circulation to study aquatic ecosystems, and is recently designated as Fundamental and Applied Limnology. The journal
Hydrobiologia (1948) has been gaining prominence in the broad scope, which gathers the majority of publications on aquatic sciences interfacing biology, including limnology and oceanography studies, most of them from Brazil and Latin America (Melo et al., 2006; Padial et al., 2008). Freshwater Biology (1971), as a journal restricted to studies of continental aquatic ecosystems includes much of the area's research. The majority of research currently conducted worldwide on the aquatic web is being published in the last two cited journals (Tao et al., 2015).

The main trends and gaps of knowledge focusing trophic interactions and food webs, biomanipulation, restorations and entire aquatic communities increased worldwide over the years. The little number of studies with experimental approaches in South America reveals the importance of high investments to experimentally test hypotheses in micro-and mesocosms. In the field and the laboratory, as there is a great interest in understanding the different trophic levels of freshwater ecosystems and their biodiversity in this region (Agostinho et al., 2005; Tundisi and Matsumura-Tundisi, 2008). The role of macrophytes promoting aquatic diversity and resources in the tropical region is still not completely understood particularly in dammed rivers (Thomaz et al., 2008). The restructuring of biological communities to restore eutrophicated lakes guided the first biomanipulation studies (Shapiro et al., 1975). The knowledge required to restore freshwater environments is acquired by information on the dynamics, structure, and interactions of the communities' trophic web (Carpenter et al., 1985). In this sense, cascade effects can be better understood through the application of experimental analyses in biomanipulation of those components as a way of restoring and increasing water quality (Carpenter et al., 1987).

Trophic interactions mediated by macrophytes in flooded environments such as swamps and reservoirs received little attention from researchers. In addition, scientometric analysis has shown that the number of studies approaching surveys methodologies is still incipient, and poorly explored (Kovalenko et al., 2011). Such type of investigation is still necessary, as this acquired knowledge support and guide new research directions (Padial et al., 2008). Besides, understanding the functioning of biological systems together, their patterns and mechanisms represent major future challenges (Thomaz and Bini, 2003). Aquatic ecosystems have become an important field of research, increasingly attracting attention from scientific communities (Liao and Huang, 2014). The present analysis shows that the contribution of economically developed countries comprise considerable investments, so, that their population has access to quality education as a production of knowledge and technology, resulting in highly qualified research (Krauskopf et al., 1995).

This scientometric analysis has identified major gaps and prospects of studies for the advancement of aquatic science in South America. Despite the appreciable number of publications, the role of macrophytes mediated trophic interactions in countries such as Brazil, Argentina and 
Uruguay still lack understanding (Kovalenko et al., 2011; Jeppesen et al., 2012). Mitigation of international asymmetries by cooperation and share of knowledge between countries and increase of scientific production in South America would be crucial to fill gaps of knowledge fundamental for ecosystems preservation.

\section{Acknowledgements}

This work was financed by the "Coordenação de Aperfeiçoamento de Pessoal de Nível Superior" (CAPES) is part of the Master's degree of the first author, undertaken within the Graduate Program in Plant Biology at the Universidade Federal de Pernambuco. This study is part of the German-Brazilian research program INNOVATE (Interplay among multiple uses of water reservoirs via innovative coupling of substance cycles in Aquatic and Terrestrial Ecosystems) with the support of the Federal Ministry of Education and Research (BMBF, 01LL0904A/E), the Ministry of Science, Technology and Innovation of Brazil (MCTI/CNPq, 490003/2012-5) and the Pernambuco Research Foundation (Facepe, APQ-0842-2.05/12). Almeida-Cortez was supported by a fellowship from Brazilian CNPq (PQ 307422/2012-7).

\section{References}

Agostinho, A., THOMAZ, S. and GOMES, L., 2005. Conservação da biodiversidade em águas continentais do Brasil. Megadiversidade, vol. 1, no. 1, pp. 71-78.

CANFIELD, D.Jr., SHIREMAN, J.V., COLLE, D.E., HALLER, W.T., WATKINS, C.E.2nd. and MACEINA, M.J., 1984. Prediction of chlorophyll-a concentrations in Florida lakes: importance of aquatic macrophytes.Canadian Journal of Fisheries and Aquatic Sciences, vol. 41, no. 3, pp. 497-501. http://dx.doi.org/10.1139/ f84-059.

CAO, X., HUANG, Y., WANG, J. and LUAN, S., 2012. Research status and trends in limnology journals: A bibliometric analysis based on SCI database.Scientometrics, vol. 92, no. 3, pp. 735-746. http://dx.doi.org/10.1007/s11192-012-0623-y.

CARPENTER, S. and LODGE, D., 1986. Effects of submersed macrophytes on ecosystem processes.Aquatic Botany, vol. 26, pp. 341-370. http://dx.doi.org/10.1016/0304-3770(86)90031-8.

CARPENTER, S., KITCHELL, J. and HODGSON, J., 1985. Cascading Trophic Interactions and Lake Productivity.Bioscience, vol. 35, no. 10, pp. 634-639. http://dx.doi.org/10.2307/1309989.

CARPENTER, S.R., KITCHELL, J., HODGSON, J.R., COCHRAN, P.A., ELSER, J.J., ELSER, M.M., LODGE, D.M., KRETCHMER, D., HE, X. and VON ENDE, C.N., 1987. Regulation of Lake Primary Productivity by Food Web Structure.Ecology, vol. 68, no. 6, pp. 1863-1876. http://dx.doi.org/10.2307/1939878. PMid:29357166.

DENT, C.L., CUMMING, G.S. and CARPENTER, S.R., 2002. Multiple states in river and lake ecosystems.Philosophical Transactions of the Royal Society of London. Series B, Biological Sciences, vol. 357, no. 1421, pp. 635-645. http://dx.doi.org/10.1098/ rstb.2001.0991. PMid:12079525.

HILL, D.L., 2004. Latin America shows rapid rise in S\&E articles. Info Brief NSF, vol. 4, no. 336, pp. 1-9.
JEPPESEN, E., SØNDERGAARD, M., LAURIDSEN, T.L., DAVIDSON, T.A., LIU, Z., MAZZEO, N., TROCHINE, C., ÖZKAN, K., JENSEN, H.S., TROLLE, D., STARLING, F., LAZZARO, X., JOHANSSON, L.S., BJERRING, R., LIBORIUSSEN, L., LARSEN, S.E., LANDKILDEHUS, F., EGEMOSE, S. and MEERHOFF, M., 2012. Biomanipulation as a Restoration Tool to Combat Eutrophication: Recent Advances and Future Challenges. Advances in Ecological Research, vol. 47, pp. 411-488. http:// dx.doi.org/10.1016/B978-0-12-398315-2.00006-5.

INSTITUTE FOR SCIENTIFIC INFORMATION - ISI. Science citation index [online]. Philadelphia: Clarivate; 2015 [viewed 14 September 2015]. Available from: http://www.webofscience.com

JEPPESEN, E., SØNDERGAARD, M., MAZZEO, N., MEERHOFF, M., BRANCO, C.C., HUSZAR, V. and SCASSO, F., 2005. Lake restoration and biomanipulation in temperate lakes: relevance for subtropical and tropical lakes. In: M.V.REDDY, ed. Restoration and management of tropical eutrophic lakes. Enfield: Science Publishers, pp. 341-359.

KOVALENKO, K., THOMAZ, S. and WARFE, D., 2011. Habitat complexity: approaches and future directions.Hydrobiologia, vol. 685, no. 1, pp. 1-17. http://dx.doi.org/10.1007/s10750-011-0974-z.

KRAUSKOPF, M., VERA, M.I., KRAUSKOPF, V. and WELLJAMSDOROF, A., 1995. A citationist perspective on science in Latin America and the Caribbean, 1981-1993.Scientometrics, vol. 34, no. 1, pp. 3-25. http://dx.doi.org/10.1007/BF02019169.

LIAO, J. and HUANG, Y., 2014. Global trend in aquatic ecosystem research from 1992 to 2011.Scientometrics, vol. 98, no. 2, pp. 1203-1219. http://dx.doi.org/10.1007/s11192-013-1071-z.

MELO, A.S., BINI, L.M. and CARVALHO, P., 2006. Brazilian articles in international journals on Limnology.Scientometrics, vol. 67, no. 2, pp. 187-199. http://dx.doi.org/10.1007/s11192006-0093-1.

PADIAL, A.A., BINI, L. and THOMAZ, S., 2008. The study of aquatic macrophytes in Neotropics: a scientometrical view of the main trends and gaps.Brazilian Journal of Biology = Revista Brasileira de Biologia, vol. 68, no. 4, suppl. 0, pp. 1051-1059. http:// dx.doi.org/10.1590/S1519-69842008000500012. PMid:19197475.

R DEVELOPMENT CORE TEAM, 2016. $R$ : A language and environment for statistical computing. Version 0.99.903 [software]. Vienna: R Foundation for Statistical Computing.

SCHEFFER, M., 1999. The effect of aquatic vegetation on turbidity; how important are the filter feeders?Hydrobiologia, vol. 408409, pp. 307-316. http://dx.doi.org/10.1023/A:1017011320148.

SCHEFFER, M., HOSPER, S.H., MEIJER, M.L., MOSS, B. and JEPPESEN, E., 1993. Alternative equilibria in shallow lakes. Trends in Ecology \& Evolution, vol. 8, no. 8, pp. 275-279. http:// dx.doi.org/10.1016/0169-5347(93)90254-M. PMid:21236168.

SHAPIRO, J., LAMARRA, V. and LYNCH, M., 1975 [viewed 12 September 2015]. Biomanipulation: an ecosystem approach to lake restoration [online]. Minnesota: Limnological Research Center, University of Minnesota, pp. 85-96. Available from: http:// www.indiana.edu/ lynchlab/PDF/Lynch2.pdf

TAO, J., CHE, R., HE, D., YAN, Y., SUI, X. and CHEN, Y., 2015. Trends and potential cautions in food web research from a bibliometric analysis.Scientometrics, vol. 105, no. 1, pp. 435-447. http://dx.doi.org/10.1007/s11192-015-1679-2.

THOMAZ, S. and BINI, L., 2003. Análise crítica sobre macrófitas aquáticas desenvolvidos no Brasil. In: S.THOMAZ and L.BINI, 
eds. Ecologia e Manejo de macrófitas aquáticas. Maringá: Universidade Estadual de Maringá, pp. 19-38.

THOMAZ, S. and CUNHA, E., 2010. The role of macrophytes in habitat structuring in aquatic ecosystems: methods of measurement, causes and consequences on animal assemblages' composition and biodiversity.Acta Limnologica Brasiliensia, vol. 22, no. 2, pp. 218-236. http://dx.doi.org/10.4322/actalb.02202011.

THOMAZ, S., et al, 2008. Influence of aquatic macrophyte habitat complexity on invertebrate abundance and richness in tropical lagoons.Freshwater Biology, vol. 53, pp. 358-367.

THOMAZ, S.M., CARVALHO, P., PADIAL, A. and KOBAYASHI, J., 2009. Temporal and spatial patterns of aquatic macrophyte diversity in the Upper Paraná River floodplain.Brazilian Journal of Biology = Revista Brasileira de Biologia, vol. 69, no. 2, suppl. 0, pp. 617-625. http://dx.doi.org/10.1590/S1519-69842009000300016. PMid:19738968.

TUNDISI, J.G. and MATSUMURA-TUNDISI, T., 2008. Biodiversity in the Neotropics: ecological, economic and social values. Brazilian Journal of Biology = Revista Brasileira de Biologia, vol. 68, no. 4, suppl. 0, pp. 913-915. http://dx.doi.org/10.1590/ S1519-69842008000500002. PMid:19197465.
TUNDISI, J.G., MATSUMURA-TUNDISI, T. and TUNDISI, J.E.M., 2008. Reservoirs and human well being: new challenges for evaluating impacts and benefits in the Neotropics.Brazilian Journal of Biology $=$ Revista Brasileira de Biologia, vol. 68, no. 4, suppl. 0, pp. 1133-1135. http://dx.doi.org/10.1590/S151969842008000500020. PMid:19197483.

VAN DONK, E. and VAN DE BUND, W., 2002. Impact of submerged macrophytes including charophytes on phyto- and zooplankton communities: allelopathy versus other mechanisms. Aquatic Botany, vol. 72, no. 3-4, pp. 261-274. http://dx.doi. org/10.1016/S0304-3770(01)00205-4.

VAN RAAN, A.F.J., 1997. Scientometrics: state-of-the-art. Scientometrics, vol. 38, no. 1, pp. 205-218. http://dx.doi. org/10.1007/BF02461131.

VERBEEK, A., DEBACKERE, K., LUWEL, M. and ZIMMERMANN, E., 2002. Measuring progress and evolution in science and technology - I: The multiple uses of bibliometric indicators.International Journal of Management Reviews, vol. 4, no. 2, pp. 179-211. http://dx.doi.org/10.1111/1468-2370.00083. 